OPEN ACCESS

Edited by:

Niels Bohse Hendriksen, Aarhus University, Denmark

Reviewed by: Elisabeth Margaretha Bik,

uBiome, United States

Pramod Kumar

All India Institute of Medical Sciences,

India

*Correspondence:

Anowara Begum

anowara@du.ac.bd

Specialty section:

This article was submitted to

Evolutionary and Genomic

Microbiology,

a section of the journal

Frontiers in Microbiology

Received: 25 September 2017

Accepted: 30 January 2018

Published: 20 February 2018

Citation:

Hossain ZZ, Farhana I, Tulsiani SM, Begum A and Jensen PKM (2018)

Transmission and Toxigenic Potential

of Vibrio cholerae in Hilsha Fish

(Tenualosa ilisha) for Human

Consumption in Bangladesh.

Front. Microbiol. 9:222

doi: 10.3389/fmicb.2018.00222

\section{Transmission and Toxigenic Potential of Vibrio cholerae in Hilsha Fish (Tenualosa ilisha) for Human Consumption in Bangladesh}

\author{
Zenat Z. Hossain ${ }^{1,2}$, Israt Farhana ${ }^{1}$, Suhella M. Tulsiani ${ }^{2,3}$, Anowara Begum ${ }^{1 *}$ and \\ Peter K. M. Jensen ${ }^{2,3}$ \\ ${ }^{1}$ Department of Microbiology, University of Dhaka, Dhaka, Bangladesh, ${ }^{2}$ Institute of Public Health, University of Copenhagen, \\ Copenhagen, Denmark, ${ }^{3}$ Copenhagen Centre for Disaster Research, University of Copenhagen, Copenhagen, Denmark
}

Fish have been considered natural reservoirs of Vibrio cholerae, the deadly diarrheal pathogen. However, little is known about the role of fish in the transmission of $\mathrm{V}$. cholerae from the Bay of Bengal to the households of rural and urban Bangladesh. This study analyzes the incidence and pathogenic potential of $V$. cholerae in Hilsha (Tenualosa ilisha), a commonly caught and consumed fish that exhibits a life cycle in both freshwater and marine environments in Bangladesh. During the period from October 2014 to October 2015, samples from the gills, recta, intestines, and scale swabs of a total of 48 fish were analyzed. The fish were collected both at local markets in the capital city Dhaka and directly from fishermen at the river. PCR analysis by targeting $V$. cholerae species-specific ompW gene revealed that 39 of 48 (81\%) fish were positive in at least one of the sample types. Real-time PCR analysis demonstrated that the cholera-causing ctxA gene was detected in $20 \%$ (8 of 39) of $V$. cholerae-positive fish. A total of $158 \mathrm{~V}$. cholerae isolates were obtained which were categorized into 35 genotypic groups. Altogether, 2501 and 133 non-01/0139 strains were isolated, which were negative for the cholera toxin gene. Other pathogenic genes such as stn/sto, hlyA, chxA, SXT, rtxC, and HA-P were detected. The type three secretion system gene cluster (TTSS) was present in 18\% (24 of 133) of non-01/0139 isolates. The antibiotic susceptibility test revealed that the isolates conferred high resistance to sulfamethoxazole-trimethoprim and kanamycin. Both $\mathrm{O} 1$ and non-01/0139 strains were able to accumulate fluid in rabbit ileal loops and caused distinctive cell death in HeLa cell. Multilocus sequence typing (MLST) showed clonal diversity among fish isolates with pandemic clones. Our data suggest a high prevalence of $V$. cholerae in Hilsha fish, which indicates that this fish could serve as a potential vehicle for $V$. cholerae transmission. Moreover, the indigenous $V$. cholerae strains isolated from Hilsha fish possess considerable virulence potential despite being quite diverse from current epidemic strains. This represents the first study of the population structure of V. cholerae associated with fish in Bangladesh.

Keywords: fish, Hilsha, Vibrio cholerae, transmission, population, pathogenic potential, Bangladesh 


\section{INTRODUCTION}

Cholera, caused by Vibrio cholerae, remains a major burden in most Asian and African developing countries. Human cholera epidemics have been mostly caused by $V$. cholerae toxigenic serogroups $\mathrm{O} 1$ and $\mathrm{O} 139$ which express two principal virulence factors, cholera toxin (CT) and the colonization factor known as toxin-coregulated pilus (TCP) (Faruque et al., 1998; Harris, 2012). The other serogroups, collectively referred to as nonO1/O139 serogroups are mostly nonpathogenic, environmental isolates that express other $\mathrm{O}$ antigens (Dziejman et al., 2005). However, some non-O1/O139 V. cholerae are clearly pathogenic and responsible for acute cholera-like diarrhea (Ramamurthy et al., 1993; Sharma et al., 1998) and a variety of extra-intestinal infections (Morris Jr and Black, 1985). Despite the lack of cholera toxin, a few pathogenic non-O1 and non-O139 strains such as O141, O10 and O12 have caused outbreaks of gastroenteritis (Bagchi et al., 1993; Dalsgaard et al., 1995; Rudra et al., 1996). Recently, genomic analysis has demonstrated that non-O1/O139 strains contributed to the early cholera outbreak in Haiti as the sole pathogen for potentially a high proportion of cases (Hasan et al., 2012). However, studies have indicated that some of the potential virulence factors such as hemagglutinin protease, repeats-in-toxin, mannose-sensitive haemagglutinin, heat-stable enterotoxin, hemolysin and type III secretion system (T3SS) are essential for the diarrheagenic mechanism of non-O1/non-O139 (Nair et al., 1988; Thelin and Taylor, 1996; Rivera et al., 2001; Dziejman et al., 2005). Animal models have been extensively used to study the pathophysiology of diarrhea caused by CT of $V$. cholerae that adheres to human intestinal mucosa and induces an inflammatory response (De and Chatterje, 1953; Singh et al., 2001; Ritchie and Waldor, 2009). Furthermore, recent investigations also suggest that other non-CT virulence factors and inflammatory responses induced by $V$. cholerae independently of CT may contribute to the pathogenesis of cholera (Hodges and Gill, 2010; Chatterjee and Chaudhuri, 2013; Sawasvirojwong et al., 2013). Therefore, both O1/O139 and nonO1/O139 serogroups of $V$. cholerae pose considerable threat to public health.

Bangladesh is an area of cholera endemicity where this disease occurs in seasonal regularity with more than 100,000 cases annually (Lipp et al., 2002; Ali et al., 2015). An annual single peak of cholera cases (March-May) is observed in rural coastal villages, whereas cholera outbreaks maintain a unique bimodal seasonality in the capital city of Dhaka, where the larger peak with the highest number of cases occurs just after the monsoon (September-November), with a smaller peak in the spring (March-May) (Kaper et al., 1995; Faruque et al., 2005; Alam et al., 2011). Major cholera outbreaks primarily originated in the coastal regions of southern Bangladesh, including the initial appearance of O139 Bengal in the coastal areas in 1992, which then spread inland through secondary means (Jutla et al., 2010). Isolation of pandemic strains from the aquatic environment of endemic regions, even during seasonal outbreaks, is rare because toxigenic strains may persist in a non-culturable state (Brayton et al., 1987; Alam et al., 2006). Vibrio cholerae may enter into a viable but non-culturable (VBNC) state to persist in the stressed conditions of aquatic environments, in which they may not form colonies on traditional bacteriological culture media (Alam et al., 2007). It is likely that the environment is the source of epidemic strains; however, the mechanism that enables spreading of $V$. cholerae across water bodies from the Bay of Bengal is still not clearly understood (Halpern et al., 2008). It has been suggested that $V$. cholerae proliferates while attached to planktonic bodies, particularly copepods, in aquatic systems (Huq et al., 1983; Colwell, 1996). Migratory water birds and fish have also been linked to $V$. cholerae dissemination between water bodies of western Asia, Europe and Africa (Halpern et al., 2008; Senderovich et al., 2010; Halpern and Izhaki, 2017). In Bangladesh, recurrent cholera infections have been linked to increased environmental concentration of plankton in river delta, although, a recent study has shown the absence of a direct connection between the riverine system and drinking water sources (Grant et al., 2015). Precisely, the transmission of $V$. cholerae between the Bay of Bengal and a major city like Dhaka still remains unknown.

It was postulated that Hilsha fish (Tenualosa ilisha), which migrates between both coastal and up-stream freshwater environments for breeding, might play a role in maintaining cholera endemicity in India (Pandit and Hora, 1951). The authors, however, failed to undertake any direct field or laboratory investigations to validate their hypothesis. Hilsha (Tenualosa ilisha) is anadromous in nature, migrating from the Bay of Bengal to inland freshwater through rivers on the Indian sub-continent for spawning, which occurs from July to October and again from January to March (Ahsan et al., 2014) (see Figure 1). The upstream migration of Hilsha is associated with the state of sexual maturity, as well as the volume of freshwater discharge from the estuary during monsoons (Bhaumik, 2017). The catch percentage of Hilsha is very high during these migratory periods. Approximately 300,000 tons of Hilsha were caught in inland and marine waters in Bangladesh from 2010 to 2011 (Ahsan et al., 2014). The availability of the fish in local markets also increased during these periods, which results in lower prices. During the remainder of the year and national festivals such as the Bengali New Year, the fish is usually too expensive for poor communities.

In this study, Hilsha fish is analyzed for the first time to be a potential carrier of $V$. cholerae, and for its role as a risk factor in the transmission of $V$. cholerae to humans. The rationale of the current study is to analyze the incidence and seasonal prevalence of $V$. cholerae in Hilsha from both the Padma River, where they have migrated from the Bay of Bengal, and in local markets in Dhaka. The study extensively characterizes the population structure of $V$. cholerae strains isolated from fish, and assesses the pathogenic potential of these strains. In addition, the clonal relationship between environmental and endemic strains was analyzed to discern the understanding of evolutionary history. The study was conducted as a part of a research project funded by the Danish Government (DANIDA) called "Combating Cholera Caused by Climate Change" (C5). The project focuses on the cholera influencing factors by identifying relative risks based on environmental and hygienic issues in Bangladesh (http://cope.ku. $\mathrm{dk} /$ research/cholera/). 


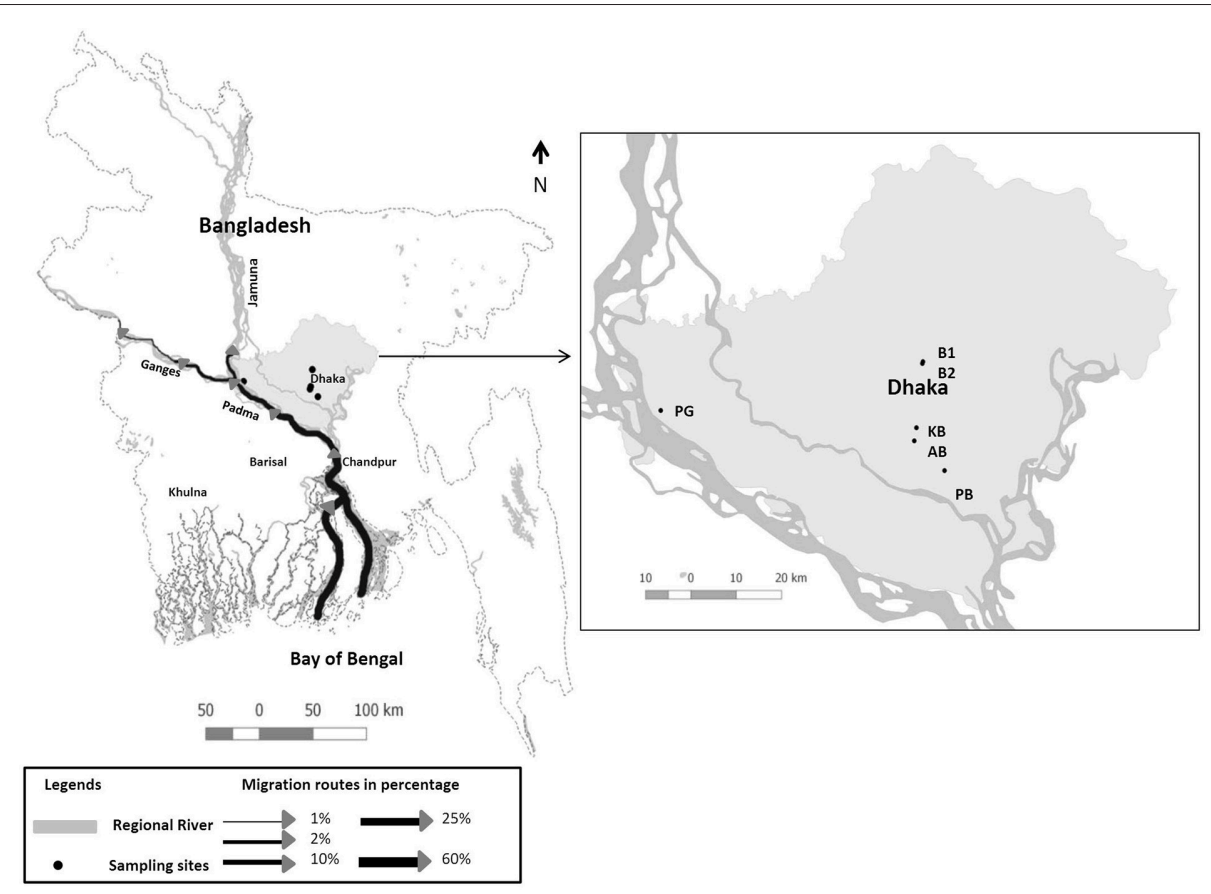

FIGURE 1 | Map showing Hilsha migration routes in Bangladesh adopted from Ahsan et al. (2014) and sample collection sites are indicated: Boubazar 1(B1), Boubazar 2 (B2), Kawran Bazar (KB), Ananadabazar (AB), Pagla bazaar (PB), and Paturiaghat (PG).

\section{MATERIALS AND METHODS}

\section{Sample Collection and Processing}

Four Hilsha fish were collected each month for a period of 1 year, from October 2014 to September 2015; two "market fish" from local markets in and around Dhaka and two "fresh fish" which were freshly caught near the bank of the Padma River (for a total of 48 fish) Figure 1, Supplementary Table 1. All the fish (mean body weight $765 \mathrm{~g}$ ) were healthy, with bright, shiny appearance and natural odor.

The fresh fish were bought directly from fishermen at the major landing point (Paturia, approximately $80 \mathrm{~km}$ away from Dhaka) early in the morning. The fish were caught on the previous night in the lower Padma River between Shariatpur and Chandpur. Each fish was collected in individual sterile collection bags and transported to the University of Dhaka laboratory within $4 \mathrm{~h}$ of collection in a cool box maintaining cold condition. Four samples were aseptically taken from each fish:- two slits of fish gills, gut, rectum and an outer swab of scales in phosphatebuffered saline (PBS). For the fish collected from the local market (fish stored on ice), ice samples where the fish were kept frozen were also collected in sterile zip-lock sample collection bags. A total of 8 and 10 samples each of fresh-caught fish and local market fish were analyzed each month for 1 year, for a final total of 96 and 120 samples. Approximately 6 gm of gill, gut and rectum samples were enriched in $60 \mathrm{~mL}$ of Alkaline Peptone Water $(\mathrm{APW})\left(1 \mathrm{~L}\right.$ distilled $\mathrm{H}_{2} \mathrm{O}, 10 \mathrm{gL}^{-1}$ peptone, $10 \mathrm{gL}^{-1}$ sodium chloride; $\mathrm{pH} 8.5$ ). One $\mathrm{mL}$ of $\mathrm{PBS}$ outer swab and storage ice water were transferred to $9 \mathrm{~mL}$ of APW for enrichment. All of the samples were incubated at $37^{\circ} \mathrm{C}$ for $24 \mathrm{~h}$.

\section{Total DNA Extraction and Detection of $V$. cholerae by Polymerase Chain Reaction}

Total DNA was extracted from all of the samples using the boiled template method (De Medici et al., 2003). The presence of Vibrio cholerae in total DNA of fish samples was confirmed by PCR using the previously published primers ( $5^{\prime}$-CACCAAGAA GGTGACTTTATTGTG- $3^{\prime}$ and $5^{\prime}$-GGTTTGTCGAATTAGCTT CACC- $\left.3^{\prime}\right)$ for the outer membrane protein $(o m p W)$ gene of $V$. cholerae (Nandi et al., 2000).

The PCR was conducted in a thermal cycler (MJ Research PTC-200, USA) using $0.2 \mathrm{~mL}$ PCR tube with a reaction volume of $12 \mu \mathrm{L}$ containing $1 \mu \mathrm{L}$ of 10X PCR buffer including $20 \mathrm{mM}$ $\mathrm{MgCl}_{2}, 0.2 \mu \mathrm{L}$ of $10 \mathrm{mM}$ deoxynucleoside triphosphates (dNTP) mix (Thermo Scientific, USA), $0.05 \mu \mathrm{L}$ of $5 \mathrm{U}$ Dream Taq DNA Polymerase (Thermo Scientific, USA) per $\mu \mathrm{L}, 0.625 \mu \mathrm{L}$ of $25 \mu \mathrm{M}$ each primer (Tag Copenhagen A/S, Denmark), 7.5 $\mu \mathrm{L}$ of nuclease-free water and $2 \mu \mathrm{L}$ of DNA template. The PCR tubes containing reaction mixtures were heated at $95^{\circ} \mathrm{C}$ for 3 min for complete denaturation of DNA templates. The PCR amplification was carried out for 35 cycles in the following order: initial denaturation at $95^{\circ} \mathrm{C}$ for $45 \mathrm{~s}$, annealing at $55^{\circ} \mathrm{C}$ for $45 \mathrm{~s}$, hybridization at $72^{\circ} \mathrm{C}$ for $45 \mathrm{~s}$, with a final extension at $72^{\circ} \mathrm{C}$ for $7 \mathrm{~min}$. PCR products (304 bp band size) were then resolved by $1.5 \%$ (wt/vol) agarose gel electrophoresis and visualized with a UV transilluminator (Gel Doc, Bio-Rad, USA) after ethidium bromide staining.

The chance of contamination between local market fish and fresh-caught fish was scored by the presence or absence of specific ompW targets and was statistically analyzed by Fisher's exact test 
for a $2 \times 2$ contingency table in statistical software $\mathrm{R}$ version 3.3.1. Significance was defined as having a $p$ value of less than 0.05 .

\section{Bacterial Strains}

A total of $158 \mathrm{~V}$. cholerae strains were isolated by using conventional cultural media TCBS (Thiosulfate citrate bilesalts sucrose agar). Species identification of all the strains was further confirmed by standard biochemical assays and $V$. cholerae species-specific ompW gene target PCR (Nandi et al., 2000; Choopun et al., 2002; Huq et al., 2012).

\section{Molecular Characterization of $V$. cholerae Isolates}

Genomic DNA from the isolates was extracted by the boiled template method described earlier. Serological assays and PCR targeting the $r f b$ sequences specific for $\mathrm{O} 1$ and $\mathrm{O} 139$ serogroups were used for further subtyping of all $V$. cholerae isolates. PCR was performed to detect the virulence and regulatory genes of $V$. cholerae O1/O139 and non O1/O139 (Supplementary Table 2). Total DNA samples that were detected as $V$. cholerae-positive were further analyzed for the presence of cholera toxin gene $(\operatorname{ctx} A)$ and the $r f b$ sequences of $\mathrm{O} 1$ and $\mathrm{O} 139$ serogroups. PCR reactions were performed by using the protocol described previously in the section Total DNA Extraction and Detection of $V$. cholerae by Polymerase Chain Reaction. The primers, probes used in this study are listed in Supplementary Table 2. Real time PCR to detect ctxA gene was performed by following the previously published protocol (Blackstone et al., 2007). Positive and negative controls used in PCR experiments are listed in Supplementary Table 3.

\section{rpoB Sequencing}

Species identities of representative $36 \mathrm{~V}$. cholerae strains were confirmed by nucleotide sequencing of $871 \mathrm{bp}$ fragment of the $r p o B$ gene. PCR based amplification and sequence analysis of $r p o B$ gene were conducted as described previously (Tarr et al., 2007). For sequencing, BigDye Terminator v3.1 sequencing kit (Applied Biosystems, USA) was used following manufacturer's instructions. Sequence determination was conducted onABI3730XL (Applied Biosystems, USA) system.

\section{Antibiotic Susceptibility Assay}

Antibiotic susceptibility of the $V$. cholerae strains was conducted by agar disk diffusion method using commercial disks (Oxoid, $\mathrm{UK})$. The strains were tested for Tetracycline $(30 \mu \mathrm{g})$, Sulfamethoxazole-trimethoprim $(25 \mu \mathrm{g})$, Chloramphenicol (30 $\mu \mathrm{g})$, Kanamycin $(30 \mu \mathrm{g})$, Neomycin $(30 \mu \mathrm{g})$ according to the standard guidelines of Clinical and Laboratory Standards Institute (CLSI) (Patel et al., 2014). The zone standards for Enterobacteriaceae were used when there were no established breakpoint interpretive criteria for $V$. cholerae. E. coli ATCC 25922 was used as quality control strain. The experiment was done in duplicate.

\section{Toxicity Assay}

Nine $V$. cholerae strains were studied including $6 \mathrm{~V}$. cholerae $\mathrm{O} 1$ and 3 non O1/O139 serogroups (Table 3) for analyzing pathogenic potential on established animal model and human cancer cell line. Multilocus sequence typing (MLST) method was used to determine the nucleotide changes in housekeeping genes of these 9 isolates compared to existing database (see section MLST below).

\section{Tissue Culture Assay}

Culture supernatants of $V$. cholerae strains were tested for cytotoxicity in HeLa cell-line (human cervical carcinoma cell-line). Following previous protocol, the cell-free culture supernatants were prepared by centrifugation and filtration through a $0.22-\mu \mathrm{m}$-pore size filter unit (Millex-GS; Millipore Corp., Bedford, Mass; Sharma et al., 1998).

HeLa cells were grown as monolayers in Dulbecco's Modified Eagles' medium (DMEM) (Thermo Fisher Scientific, USA) containing $1 \%$ penicillin-streptomycin (1:1) and $0.2 \%$ gentamycin and $10 \%$ fetal bovine serum (FBS). Cells $(4.4 \times$ $10^{4} / 400 \mu \mathrm{l}$ ) were seeded onto 24 -well plates and incubated overnight at $37^{\circ} \mathrm{C}$ in a humidified $5 \% \quad \mathrm{CO}_{2}$ atmosphere. Thereafter, $100 \mu \mathrm{l}$ of the culture supernatant sample was added each well. Cytotoxicity was examined under an inverted light microscope (Olympus, Japan) after $24 \mathrm{~h}$ of incubation. The uninoculated Trypticase soy broth and $V$. cholerae O1 El Tor N16961were used as negative and positive control. Duplicate wells were used for each sample.

\section{Rabbit lleal Loop Assay}

Cultures of Vibrio cholerae were tested for ileal loop fluid accumulation in adult New Zealand albino rabbits as described (De and Chatterje, 1953). The experiments were performed at International Centre for Diarrheal Disease (icddr, b) Bangladesh in complete accordance with icddr, b ethical guidelines. The protocol was reviewed and approved by icddr, b "Animal Experimentation Ethics Committee (AEEC)." Each test was done in duplicate (in two rabbits). Toxigenic V. cholerae N16961 and PBS were used as positive and negative control respectively. $V$. cholerae strains with little or no fluid accumulation in the initial passage were recovered from the ileal loops on nutrient agar plates and subjected to second passage in the same way by using the protocol of Sanyal et al. (1984). This process was repeated until third passage to obtain unambiguous positive response.

\section{Multilocus Sequence Typing}

Seven house-keeping genes ( $a d k, g y r B, m d h$, metE, purM, $p n t A$, and $p y r C$ ) were recovered by PCR from all nine strains and the products were sequenced. The primer sequences were extracted from previously published work (Octavia et al., 2013). Homologous sequences from these seven loci were sourced from database entries of whole and partial sequences with the following genome strains and accession nos.N16961 (Accession No.AE003852); BX330286 (Accession No. ACIA00000000); MZO-3 (Accession No. AAUU00000000); M2552 (KC894993, KC895055, KC895117, KC895179, KC89524, KC895303, KC895365); M2554 (KC894995, 
KC895057, KC895119, KC895181, KC895243, KC895305, KC895367); M1619 (KC894986, KC895048, KC895110, KC895172, KC895234, KC895296, KC895358). Sequences for the fish isolates are deposited in GenBank under accession nos. KY619689-KY619697 (adk), KY619698-KY619706 (gyrB), KY619707-KY619715 (mdh), KY619716-KY619724 (metE), KY619725-KY619733 (pntA), KY629640-KY629648 (purM), KY629649-KY629657 (pyrC).

A multiple alignment of sequences generated by the study and those extracted from the Genbank database was constructed using MAUVE software package (http://asap.ahabs. wisc.edu/software/). The aligned file was used as input for Bayesian inference of genealogy and recombination events using CLONALFRAME v. 1.2 software following the published method along with model parameters (Didelot and Falush, 2007; Islam et al., 2013). The number of populations was determined by the Markov Chain Monte Carlo (MCMC) simulation of 10,000 iterations which gave the posterior probability of $K$ following a burn-in of 10,000 iterations and parameter values were recorded for 10 iterations in the posterior sample. Analysis was repeated three times with same data and parameters, but with distinct starting points and $50 \%$ consensus trees were produced by Clonal Frame with a threshold of 0.5 . The relative effect of homologous recombination on the genetic diversification of populations was measured by calculating the ratio of recombination and mutation events (r/m) (Guttman and Dykhuizen, 1994).

\section{Ethics Statement}

This study was undertaken in accordance with the ethical recommendation of Faculty of Biological Sciences, University of Dhaka, Bangladesh. All the fish for this study were obtained directly from fishermen and fish mongers in local markets selling for consumption. The fish were not alive during the time of collection.

\section{RESULTS}

\section{Prevalence of $\boldsymbol{V}$. cholerae in Fish Samples}

Of the total of 48 individual fish (216 total DNA samples) collected, 39 (81\%) fish were positive for the specific ompW gene when assayed for $V$. cholerae. Among the market fish, detection was highest in the gills (19 of 24 fish, 79\%), followed by outer scale swabs, recta and intestines. In fresh fish, detection was highest in outer scale swabs (16 of 24 fish, $66.7 \%$ ), followed by the gills, recta and intestines (Figure 2). Seventeen storage ice samples were positive for $V$. cholerae out of $24(70.8 \%)$ market fish by PCR. No local market fish was found to be positive only for ice water. The presence of $V$. cholerae was higher in fish purchased from local markets $(21$ of $24,87.5 \%)$ by PCR than fish from the river banks (18 of $24,75 \%$ ), where the fish were considered positive if any part of the fish was positive. A total of 55\% (53 of 96) of fresh fish sample types and 60\% (72 of 120) of local fish sample types including ice samples were found to be positive for $V$. cholerae.

The prevalence of $V$. cholerae contamination was statistically compared between the fish types. Statistical analysis using Fisher's exact test yielded that the chance of $V$. cholerae contamination in market fish stored on ice is higher than in fresh fish and showed

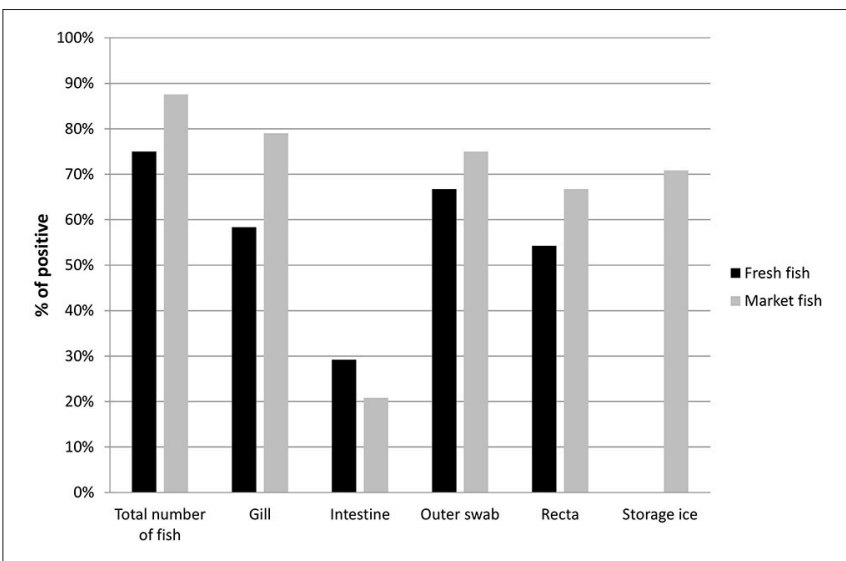

FIGURE 2 | Prevalence of $V$. cholerae in total number of fish (Fresh fish, $n=$ 24 and Market fish, $n=24$ ) and different fish parts (no ice was collected for any of the fresh fish). Positivity of $V$. cholerae was determined by ompW gene target PCR.

a significant difference (odds ratio [OR]: 0.41; 95\% confidence interval $[\mathrm{CI}]: 0.2,0.9 ; P=0.03)$. No statistically significant difference was found $(P=0.6)$ when the analysis was done on total individual samples (96 from fresh fish and 120 from local market fish).

\section{Molecular Genotyping of Total DNA and Monthly Incidence}

Total DNA samples were extracted from Hilsha fish and ice samples for $V$. cholerae detection and isolation. Among them, 125 (58\%) samples tested positive based on the ompW PCR. The ompW positive total DNA samples were further characterized by targeting genes of toxigenic $V$. cholerae, which yielded 25 positive amplicons (16 fish) for the $V$. cholerae O1 serogroup and 9 (6 fish) for the $\mathrm{O} 139$ serogroup. Seven of the $V$. cholerae O1-positive and three of the O139-positive samples were also positive for $c t x A$ in real-time PCR which comprised $8 \%$ of all $V$. cholerae-positive samples and $20 \%$ of all $V$. cholerae-positive fish. Detection of $V$. cholerae $\mathrm{O} 1, \mathrm{O} 139$ and $\operatorname{ct} x A$ genes was compared between the two types of fish, and $23.8 \%$ ( 5 out of 21 ) of local market fish were found to be positive for the ctxA gene, an amount that was higher than for fresh fish samples (16.67\%, 3 out of 18). The results are shown in Table 1. The detection of $r f b O 1$ and $\operatorname{ctxA}$ gene was confirmed as positive in $11.8 \%$ ( 2 out of 17 ) and $5.9 \%$ ( 1 out of 17 ) ompW positive storage ice samples respectively and none were positive for $r f b O 139$ gene. One market fish was found $c t x A$ gene positive in ice only, whilst the other parts were negative.

The monthly incidence of $V$. cholerae in fish revealed two annual peaks; one from March to June before the monsoon, followed by a second peak in August-November at late monsoon (Figure 3). Detection of DNA from toxigenic V. cholerae $\mathrm{O} 1$ and cholera toxin peaked in April when 100\% (4 of 4) of the fish were positive for both the $r f b O 1$ and $c t x A$ genes. Detection of $V$. cholerae O139 was highest in July and September when 50\% (2 of 4) of all the fish were positive for the $r f b O 139$ gene. 
TABLE 1 | Occurrence of toxigenic $V$. cholerae genes in fresh and market fish.

\begin{tabular}{|c|c|c|c|c|c|c|c|c|}
\hline $\begin{array}{l}\text { Fish } \\
\text { types }\end{array}$ & $\begin{array}{c}\text { No. of } \\
\text { V. cholerae } \\
\text { positive } \\
\text { fish/total (\%) }\end{array}$ & $\begin{array}{c}\text { No. of } V \text {. cholerae } \\
\text { positive samples } \\
\text { /total }(\%)\end{array}$ & $\begin{array}{c}\text { No. of } \\
\text { V. cholerae } \\
\text { O1 positive } \\
\text { fish/total (\%) }\end{array}$ & $\begin{array}{c}\text { No. of } V . \text { cholerae } \\
\text { O1 positive } \\
\text { samples/total (\%) }\end{array}$ & $\begin{array}{c}\text { No. of } \\
\text { V. cholerae } \\
\text { O139 positive } \\
\text { fish/total }(\%)\end{array}$ & $\begin{array}{c}\text { No. of } \\
\text { V. cholerae } \\
\text { O139 positive } \\
\text { samples/total }\end{array}$ & $\begin{array}{l}\text { No. of ctxA } \\
\text { positive fish/ } \\
\text { total (\%) }\end{array}$ & $\begin{array}{c}\text { No. of ctxA } \\
\text { positive } \\
\text { samples/total } \\
(\%)\end{array}$ \\
\hline Fresh fish & $18 / 24(75)$ & 53/96 (55.2) & 6/18 (33.3) & 8/53 (15) & 2/18 (11.1) & $3 / 53$ (5.7) & $3 / 18(16.67)$ & 4/53 (7.5) \\
\hline $\begin{array}{l}\text { Market } \\
\text { fish }\end{array}$ & 21/24 (87.5) & $72 / 120$ (60) & $10 / 21(47.6)$ & 17/72 (23) & 4/21 (19) & 6/72 (8.3) & $5 / 21(23.8)$ & 6/72 (8.3) \\
\hline
\end{tabular}

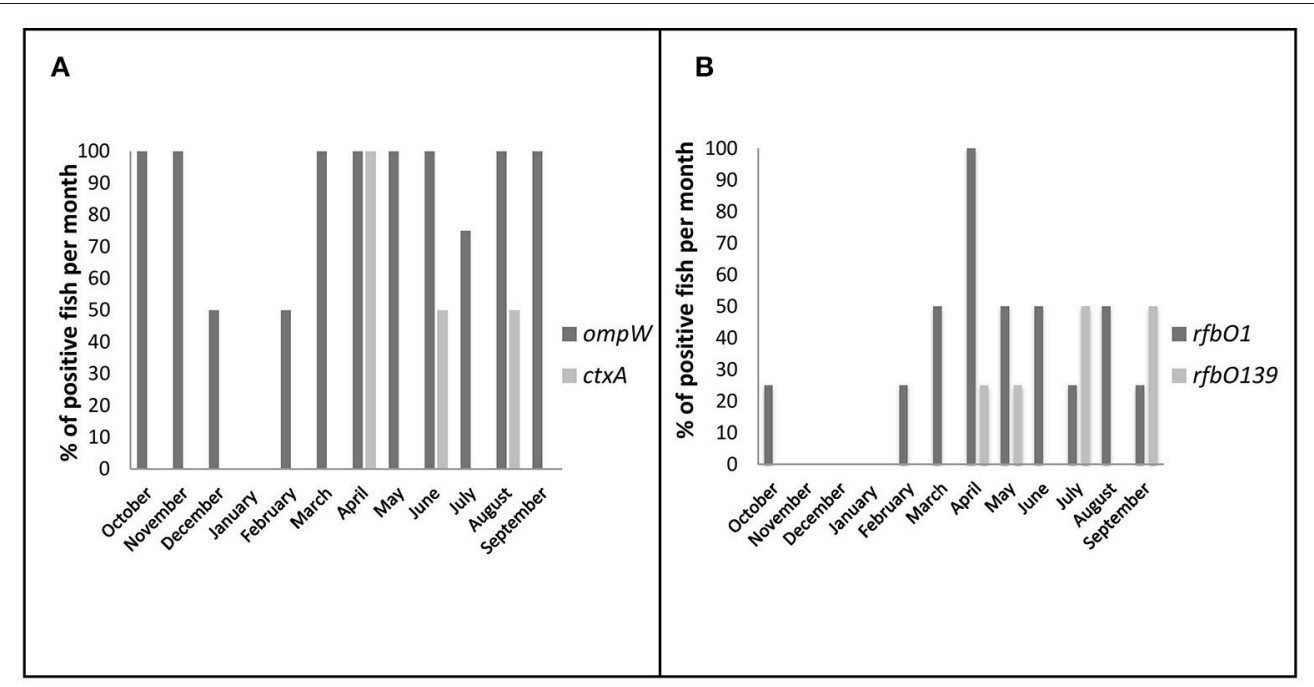

FIGURE 3 | Seasonal variation of total and toxigenic $V$. cholerae prevalence in direct DNA samples (\%, bar chart). The fish was considered as positive when any part of the fish was found positive in PCR (including ice samples of market fish). (A) Positive fish per month for ompW and ctxA genes (B) Positive fish per month for toxigenic serogroups $\mathrm{O} 1$ and $\mathrm{O} 139$.

\section{Genotyping of $\boldsymbol{V}$. cholerae Strains}

A total of 158 strains isolated from fish were confirmed as $V$. cholerae species by cultural and biochemical tests and ompW gene specific PCR. A total of 35 groups of 158 strains were detected using PCR based genotypic characterization (Supplementary Table 2). Twenty-five $V$. cholerae strains were positive for the $r f b O 1$ gene and 133 strains were negative (non O1/O139), which are included in 13 and 23 groups respectively (Table 2). None were positive for the $r f b O 139$ gene and none of the $\mathrm{O} 1$ strains contained cholera toxin genes $\mathrm{A}$ and $\mathrm{B}$ (ctxA and $c t x B)$, the toxin-coregulated pilus $(t c p)$, colonization factor (ace), and core-encoded pilus (cep) genes. The highest numbers of isolates (29) in our study were categorized in Group-XXIX with a genotypic trait of $r f b O 1^{-} \operatorname{ch} x A+m s h A+o m p U+$. The heat stable enterotoxin of $V$. cholerae ( $\mathrm{stn} / \mathrm{sto}$ ) was present in three out of $25 \mathrm{O} 1$ strains and four out of 133 non-O1 strains. We studied the SXT mobile genetic element that encodes antibiotic resistance in all the strains, and 37 strains (4 O1 and 33 non O1/O139) were positive. Twenty-four (18\%) non-O1 strains were positive by PCR for all three genes ( $v c s N 2, v c s C 2, v o p F)$ tested for type three secretion system. Sixty-eight percent $\mathrm{O} 1$ and $80 \%$ non-O1 experimental strains possessed mannose sensitive hemagglutinin pilus $(m s h A)$. Previous studies show that newly discovered Cholix toxin $(\operatorname{ch} x A)$ is mostly found in non O1 $V$. cholerae (Awasthi et al., 2013). However, approximately $80 \%$ of the O1, and $71 \%$ of the non $\mathrm{O} 1$ strains of this study were positive for the $\operatorname{ch} x \mathrm{~A}$ gene. The gene of the putative outer membrane protein (ompU) was found in 14 (56\%) O1 and 62 (47\%) non-O1 strains. All the strains were positive for hemolysin hlyA, hemagglutinin protease (HA- protease), toxR, rtxC, and the type six secretion system (vasA, vasH, vasK) PCR. Isolation of $V$. cholerae dropped in January and remained the same for the next 2 months.

A total of 35 representative Vibrio cholerae strains of 35 genotypic groups were sequenced to identify those that showed different molecular characteristics. The partial nucleotide sequences of the $r p o B$ gene have been evaluated for species identification of $V$. cholerae. The alignment of the study sequences to databases using BlastN (http://blast.ncbi.nlm.nih. gov/Blast.cgi) confirmed $99-100 \%$ sequence similarity with $V$. cholerae species. Isolate information and accession numbers are listed in Supplementary Table 4.

\section{Antibiotic Sensitivity Test}

All the $V$. cholerae strains $(n=158)$ were tested for their antibiotic susceptibility against five commonly prescribed antibiotics. The antibiotic response of the strains revealed that all were uniformly susceptible to Chloramphenicol (100\%). Two (1\%), $17(10 \%), 15(9 \%)$ and $10(6 \%)$ isolates were found 
TABLE 2 | Grouping of $V$. cholerae isolates based on genotypic characterization.

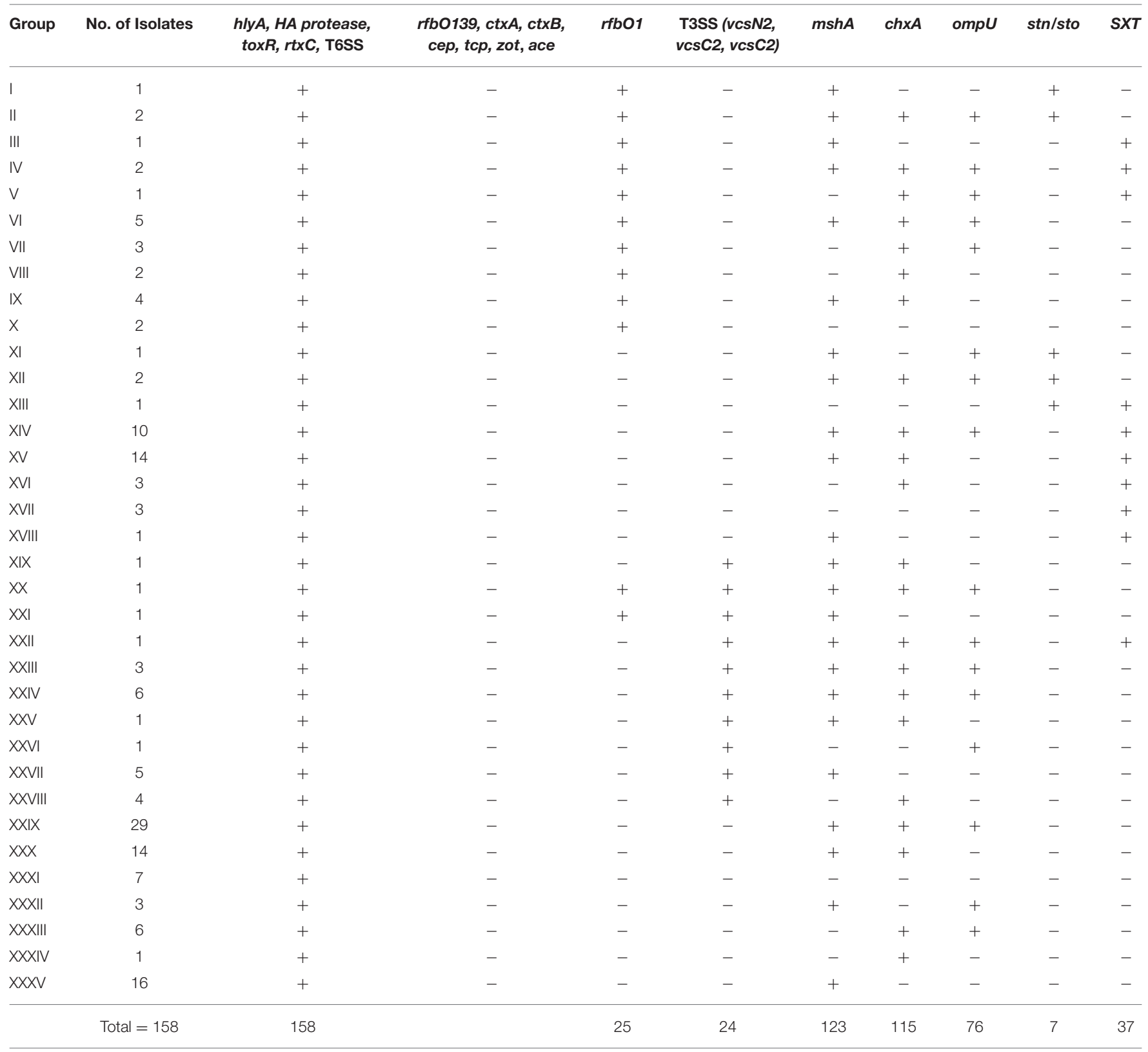

to be resistant to tetracycline, Sulfamethoxazole-trimethoprim, kanamycin, and neomycin respectively. Thirty-five isolates showed antimicrobial drug resistance to at least one of the test antibiotics. All these strains carried the gene for the SXT mobile genetic element. The results are shown in Figure 4.

\section{Pathogenicity Assays}

Cell-free culture supernatants of nine Vibrio cholerae isolates caused morphological changing from cell rounding to cell clumping and cell death of the HeLa cell line. Six of the nine isolates were cytotoxic, three of these (F-44, F-52a, F$91 b)$ induced massive cell death ( $<1 \%$ survival of HeLa cells), indicating the presence of extracellular cytotoxic proteins. The severity of cytotoxicity was relatively less apparent in the supernatants of F-45 and 49d. Three isolates, F-36a, F-47, and F-53 exhibited negligible cytotoxicity with survival of more than $90 \%$ of HeLa cells. Morphological changes induced by cell-free culture supernatants of $V$. cholerae were detected by microscopic examinations. Compared to the fish isolates, the positive control $V$. cholerae O1 N16961 in this assay showed a lower cytotoxic effect.

All nine isolates were tested for their ability to cause fluid accumulation in the rabbit ileal loop model. All strains except F$36 \mathrm{a}$ had an FA index above the borderline of 0.5 , the accepted cut-off for FA in diarrheagenic bacterial strains (Wallis et al., 1986; Islam et al., 2013). Six isolates caused fluid accumulation 
(FA index, 0.5-1.8) in the initial passage (Table 3). Isolate F45 showed a positive response after three passages. The control strains N16961 showed a mean fluid accumulation of $1.6 \mathrm{~mL} / \mathrm{cm}$.

\section{Multilocus Sequence Typing Analysis}

A consensus tree of genealogy was constructed by ClonalFrame software which demonstrates clonality of the population data (Figure 5). The fish isolates clustered into four major clades; of which three clades comprised of draft sequences from database as neighbor. One of these groups consists of isolate F-91b, $V$. cholerae strain N16961 and BX 330286, both of the database strains are toxigenic O1 El Tor but interestingly, BX 330286 was isolated from water samples in Australia. Another group comprises of $V$. cholerae strain M2552, MZO-3 and F-32b.The first two strains are clinical non-O1 isolates but the fish strain contains $r f b O 1$ gene but lacks ctxA gene. The third clade comprises F-36a, F-44, and V. cholerae strain M1619; the former two fish strains have almost similar virulence gene profile since F-44 only lacks ompU gene. Strain M1619, a non-O1/O139 $V$. cholerae, was recovered from environment in Australia and

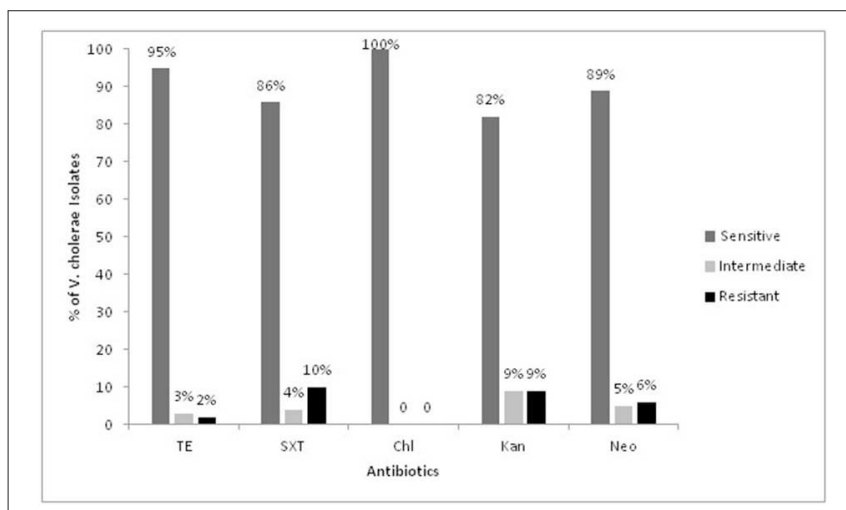

FIGURE 4 | Antibiotic susceptibility pattern of the Vibrio cholerae isolates. TE, Tetracycline; SXT, Sulfomethoxazole-trimethoprim; Chl, Chloramphenicol; Kan, Kanamycin; Neo, Neomycin. identified as carrying the VPI (Vibrio Pathogenicity Island) and CTX phage region. The cluster formation in sets of sequence types predicts the occurrence of recombination or point mutation in different alleles. Our analysis implies recombination events occur more often relative to mutation in study population. In the case of the seven genes analyzed here, the ratio of probabilities of nucleotide substitution through recombination and mutation $(\mathrm{r} / \mathrm{m})$ is 0.4 that means recombination induces evolution events 0.4 times higher than point mutations.

\section{DISCUSSION}

To the best of our knowledge, this is the only study on $V$. cholerae occurrence in Hilsha, a fish that migrates from choleraendemic coastal waters upstream to freshwater rivers running through Bangladesh. Here, we show the population dynamics of $V$. cholerae strains isolated from freshly caught and local market Hilsha fish of Bangladesh and map their virulence profile and toxigenic potential. This study is the first to profile virulence related genes of $V$. cholerae in Hilsha fish.

Our results suggest that Hilsha fish may serve as a possible transmission vehicle of $V$. cholerae from the Bay of Bengal to inland Bangladesh due to their unique survival practices, such as migration for breeding and planktonic food. Previously, Bhuyan et al. (2016) reported the role of flooding in the seasonal dissemination of $V$. cholerae from coastal to inland water bodies in India, which corresponds with our investigation as the main period of Hilsha migration is during flooding caused by monsoon rains (Islam et al., 2016). Unlike the study conducted by Bhuyan et al. (2016), river water contamination was not analyzed in this study. Although there was a limited number of fish analyzed in our preliminary study, the data indicate that the occurrence of $V$. cholerae in Hilsha fish maintains similarity with the seasonal regularity of cholera epidemics in Bangladesh. The detection of $c t x A$-positive samples was highest in April. The presence of non-toxigenic O1/O139 and non-O1/O139 in fish may also play a critical role in cholera evolution and transmission, as they share the same environmental habitats as O1/O139 serogroups

TABLE 3 | Results of pathogenicity assays.

\begin{tabular}{|c|c|c|c|c|}
\hline \multirow[t]{2}{*}{ Isolate ID (genotypic group) } & \multirow[t]{2}{*}{ Fish part from where isolated } & \multirow[t]{2}{*}{ rfb 01} & \multirow[t]{2}{*}{ Cytotoxic effect (survival of HeLa cells) } & \multirow{2}{*}{$\frac{\text { Rabbit ileal loop assay }}{\text { Mean FA index (V/L)* }}$} \\
\hline & & & & \\
\hline F-32b (l) & Outer surface & + & Cytotoxic (10-30\%) & $1.78(1)$ \\
\hline F-36a (VII) & Gill & + & Non cytotoxic (>90\%) & $0.46(3)$ \\
\hline $\mathrm{F}-44(\mathrm{VIII})$ & Gut & + & Cytotoxic (<1\%) & $1.29(1)$ \\
\hline $\mathrm{F}-45(\mathrm{IX})$ & Gill & + & Cytotoxic (<40\%) & $0.67(3)$ \\
\hline F-47 (XXIII) & Storage ice & - & Non cytotoxic (>95\%) & $0.87(2)$ \\
\hline $\mathrm{F}-49 \mathrm{~d}(\mathrm{XIX})$ & Storage ice & - & Cytotoxic (20-50\%) & $0.53(1)$ \\
\hline F-52a (XXVI) & Rectum & - & Cytotoxic (<1\%) & $1.44(1)$ \\
\hline F-53 (IX) & Outer surface & + & Non cytotoxic (>95\%) & $1.73(1)$ \\
\hline F-91b (VIII) & Outer surface & + & Cytotoxic (<1\%) & $1.25(1)$ \\
\hline
\end{tabular}

*V, Volume of fluid in $\mathrm{mL}$; L, Length of the loop in $\mathrm{cm}$. Number of passages in bracket.

Positive cut-off value $=0.5 \mathrm{~mL} / \mathrm{cm}$. 


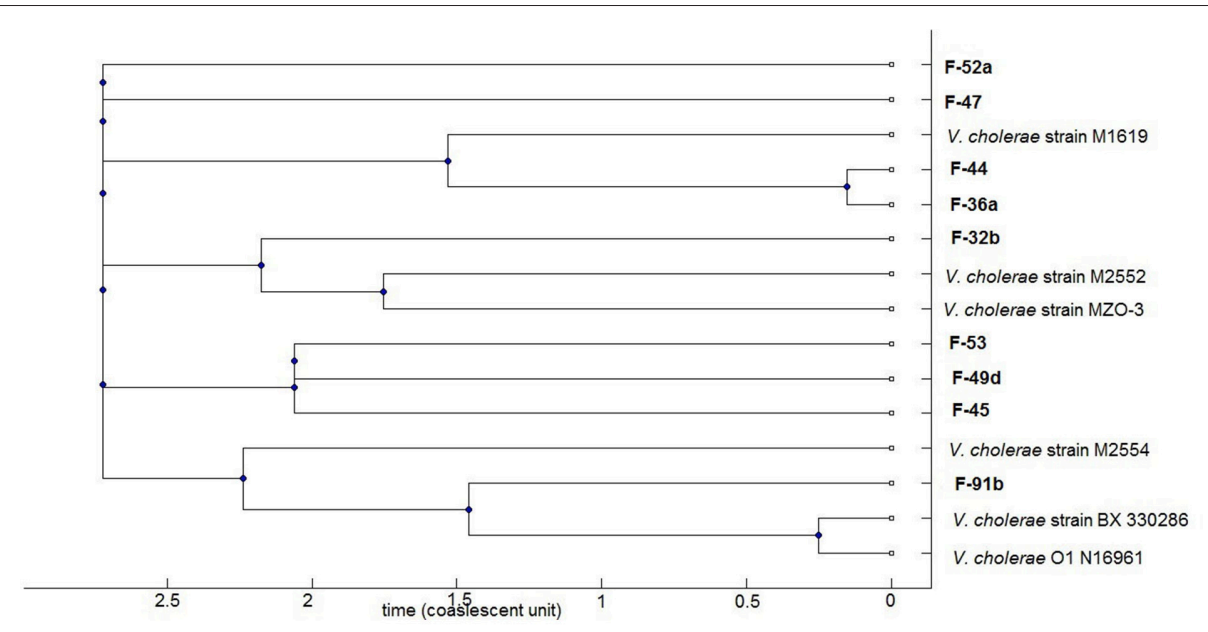

FIGURE 5 | Phylogenomic tree based on concatenated multilocus sequences of the $V$. cholerae strains. The current study $V$. cholerae strains are highlighted as bold which comprises both $\mathrm{O} 1$ and non-O1 strains. The remaining strains representing clinical and environmental toxigenic $\mathrm{O} 1$ and non-O1 reference strains: strain M1619, environmental toxigenic non-O1; strain M2552, M2554, and MZO-3, clinical non-O1; strain BX330286, environmental toxigenic O1; strain N16961, clinical O1.

(Azarian et al., 2016). A higher occurrence of toxigenic $V$. cholerae genes is seen in the local market fish. A possible explanation for this observation is that unhygienic conditions for fish storage could make the fish more prone to crosscontamination with fecal matter.

Vibrio cholerae has been isolated from other fish species including fresh water Tilapia species in Israel, Burkina Faso, and Tanzania (Senderovich et al., 2010; Traor et al., 2014; Hounmanou et al., 2016), from Ayu fish in the rivers of Japan (Kiiyukia et al., 1992), from the species Rastrineobola argentea and Oreochromis niloticus in Lake Victoria, Kenya (Onyuka et al., 2011), and from ornamental fish in Czech Republic (Rehulka et al., 2015). Reports also demonstrate isolation of $V$. cholerae from marine fish species (Scheelbeek et al., 2009; Senderovich et al., 2010). Furthermore, Mrityunjoy et al. (2013) showed elevated bacterial load in frozen fish collected from Dhaka city in Bangladesh. So far, no studies have been undertaken to investigate the bacterial genomic characteristics isolated from fish of the Ganges Delta region and Bangladesh, where cholera is endemic.

Fish has been indicated as the source of cholera outbreaks in different continents. Cholera has been associated with consumption of raw fish and seafood (McIntyre et al., 1979; Maggi et al., 1997; Forssman et al., 2007). A cholera patient was identified in Berlin, who had become infected while handling and preparing imported fish from Nigeria (Schürmann et al., 2002). Although, fish accounts for approximately $66 \%$ of total animal food intake in Bangladesh (Belton et al., 2011), there is no study to our knowledge that examined fish as a transmission risk factor for cholera outbreaks. Hilsha (Tenualosa ilisha) is the most important fish species in Bangladesh, which alone contributes to more than $10 \%$ of the total fish catch (Ahsan et al., 2014).

A low-income area near Dhaka was selected in which to directly contact households for information on where they purchase their fish. Fishmongers were also asked about the source of their fish. In Bangladesh, fish are normally bought whole without cleaning and taken home to be gutted and cleaned by members of the household themselves. The gutting and slicing of fish normally occurs on the kitchen floor with a water source nearby. Lack of proper hand washing and reusing water for cleaning cutting materials is also observed in overcrowded urban communities with mixed incomes. Factors such as shared cooking areas and inadequate drainage systems lead to susceptibility to cholera infection in these neighborhoods (Wahed et al., 2013). This combination of attributes has been previously reported in a study in Monrovia, Liberia, which suggested a cholera transmission pattern based on the cleaning of fish, rather than its consumption (Scheelbeek et al., 2009).

Vibrio cholerae was isolated from 35 of 40 fish (115 of 125 positive fish specimen types) to test for $V$. cholerae specific PCR. Multiple isolates with different cultural and genotypic properties have been isolated from 6 fish (14 fish specimens) and isolation was not successful for $5 \mathrm{~V}$. cholerae positive fish (10 fish specimens). The strains successfully isolated in this study were of nontoxigenic $\mathrm{O} 1$ and non-O1/O139 serogroups. None of the $\mathrm{O} 1$ isolates carried the genes for the major toxin genes $c t x A$ and tcp, to which the clinical state of cholera is primarily attributed. Previous studies have shown that the $\mathrm{O} 1$ serogroup of $V$. cholerae frequently isolated from the aquatic environment commonly lack cholera toxin genes (Igbinosa and Okoh, 2008). In our study, the presence of the ctxA gene in direct DNA samples has been observed, but we have not succeeded in isolating these pathogenic strains. Difficulties in culturing cholera bacteria from environmental samples have been reported in previous studies. However, it has been shown that on average, culturing yielded positive results for only $1 \%$ of the environmental samples analyzed during epidemic periods, and rarely during interepidemic periods as cells enter 
into a viable but non-culturable (VBNC) state (Huq et al., 1990; Alam et al., 2006; Du Preez et al., 2010; Bhuyan et al., 2016). Fluctuations of environmental factors and the abundance of nontoxigenic isolates in the aquatic system may have an impact on the isolation of pathogenic strains (Mishra et al., 2012). It is noteworthy that small sample size and limited fish collection points could also be limiting factors in this study.

Toxigenic non-O1/O139 serogroups have caused severe cholera-like outbreaks in India and other countries, including Haiti (Rudra et al., 1996; Dalsgaard et al., 1999; Onifade et al., 2011; Hasan et al., 2012). Two toxigenic V. cholerae O1 strains, positive for cholera toxin, have been isolated from Tilapia fish gill, harvested in sewage stabilization ponds in Tanzania and 5 O1 strains were isolated from two marine fish in Cochin, India during 2009-2011 (Kumar and Lalitha, 2013; Hounmanou et al., 2016). The presence of pathogenic serogroups $\mathrm{O} 1$ and $\mathrm{O} 139$ in fish scale samples collected in Mozambique have been detected by direct fluorescent antibody technique but the researchers were unable to culture them (Du Preez et al., 2010). In contrast, non-O1/O139 serogroups are prevalent worldwide in both freshwater and marine fish (Senderovich et al., 2010; Jones et al., 2013; Traor et al., 2014).

PCR based genotypic analysis revealed variability among the isolates, with 35 genotypic profiles comprising of 19 virulence factors (Table 2). Virulence factors other than cholera toxin are present in the isolates for example, both $\mathrm{O} 1$ and nonO1 strains were found to contain cholix toxin gene $(\operatorname{ch} x A)$, a potent cytotoxin that is capable of halting protein synthesis in eukaryotic cells (Purdy et al., 2010) and the stn/sto gene for a heat-stable enterotoxin produced by toxigenic $V$. cholerae and E. coli (Rivera et al., 2001). Genes for the type III secretion system (TTSS) were detected in $18 \%$ of non-O1/O139 fish isolates. The major role of the TTSS in pathogenesis of nonO1/O139 V. cholerae induced diarrhea is already established (Dziejman et al., 2005). Infant rabbits orally inoculated with the wild type non-O1 strain AM-19226, which carries the gene for the TTSS, rapidly elicited a fatal diarrheal disease, and induced disruptions of the intestinal epithelium (Shin et al., 2011). Hemolysin, another virulence factor present in $V$. cholerae, promotes chloride secretion from intact human intestinal mucosa and capable of blood cell lysis in humans (Debellis et al., 2009). Reports indicate strains of non-O1/O139 $V$. cholerae isolates from hospitalized diarrheal patients in Kolkata, India, contained only the hemolysin ( $h l y A)$ gene, while negative for all other major toxin genes of $V$. cholerae (Chatterjee et al., 2009; Senderovich et al., 2010). The hemolysin gene $(h l y A)$ was present in all fish isolates of this study. Another ubiquitously found virulence factor in this study was the type 6 secretion system (T6SS). Unterweger et al. (2012) reported that $V$. cholerae employs T6SS to compete commensal bacteria both in the human intestine and environment. The self-transmissible mobile genetic element termed the SXT element, have a crucial role in transferring antimicrobial drug resistance genes among microbial populations by conjugation (Toma et al., 2005). The SXT element of $V$. cholerae confers resistance to sulfamethoxazole, trimethoprim, chloramphenicol, and streptomycin (Waldor et al., 1996). In this study, 37 fish isolates contain the gene for the SXT element. Among them, 35 isolates showed resistance to at least one of the antibiotics tested, except for Chloramphenicol.

In the absence of CT and major colonization factors, culture supernatants of 4 non-toxigenic O1 (4 of 6 investigated) and 2 non-O1/O139 (2 of 3 investgated) strains showed a positve cytotoxic effect on HeLa cells by a mechanism which remains to be further characterized. Studies with non-O1/O139 strains showed a range of determinants for cytotoxicity, including hemolysins (Coelho et al., 2000), cholix toxin (Jørgensen et al., 2008), and heat stable enterotoxin (Arita et al., 1986). In this study, 4 cytotoxic strains possess $\operatorname{ch} x A, 1$ possesses stn/sto gene, and all the strains $(\mathrm{n}=6)$ contained the hlyA gene. Eight of the nine strains showed a phenotype (fluid accumulation) in in vivo animal models similar to human disease despite the absence of major cholera toxin. Our results showed similar concordance with the previous reports of evoking fluid accumulation in the ileal loop test, despite lacking the CTX virulence cassette in V. cholerae O1 (Koley et al., 1999; Rajpara et al., 2013). Two non-O1/O139 fish strains possess a TTSS which mediates human diarrheal disease. Despite the high degree of virulence diversity, some fish strains showed genetic relatedness with pathogenic clones of diverse geographical locations. For example, the nontoxigenic O1 isolate F-91b fell in the same clade with toxigenic O1 N16961 and BX 330286 isolated from Bangladesh and Australia, respectively. These clonal relationships among fish and pandemic strains indicate that Hilsha fish may act as an environmental habitat where new pathogenic strains may emerge their non-pathogenic progenitors.

In conclusion, as cases of cholera in Bangladesh continue to occur, new transmission dynamics and their potential influence on virulence should be monitored. This study presents new data on the prevalence of Vibrio cholerae in Hilsha fish, and the possibility of an alternative route of transmission to households (as opposed to drinking water) in Bangladesh. The spectrum of the $V$. cholerae population isolated from Hilsha fish samples was highly heterogeneous, based on genotypic profile analyses. Nevertheless, the Vibrio cholerae isolates lacked cholera toxin, yet in vitro and in vivo activity showed the disease potential of the isolates. Despite the presence of the cholera toxin gene in Hilsha fish samples, isolation of toxigenic strains was not successful. Still it demands close monitoring of the coastal catch of Hilsha fish for cholera transmission and public health awareness to minimize the health risk posed by non-cholera Vibrio serogroups.

\section{AUTHOR CONTRIBUTIONS}

$\mathrm{ZH}$ designed and carried out the study in the laboratory, analyzed the results and wrote the original draft. IF collected the samples, carried out the laboratory work and participated in acquisition of data. ST participated in critical reviewing and editing of original draft. PJ and $\mathrm{AB}$ conceived of the study and contributed to the 
revision of the draft and final approval of the version to be published. PJ was the principal supervisor of the project. All authors read and approved the final manuscript.

\section{FUNDING}

This study was funded by the project entitled "Combating Cholera Caused by Climate Change in Bangladesh, C5” (Grant no. 12-040KU) from Danish International Development Agency (DANIDA).

\section{REFERENCES}

Ahsan, D., Naser, N., Bhoumik, U., Hazra, S., and Bhattacharya, S. (2014). Migration, Spawning Patterns and Conservation of Hilsa Shad (Tenualosa ilisha) in Bangladesh and India. New Delhi: Academic Foundation.

Alam, M., Islam, A., Bhuiyan, N. A., Rahim, N., Hossain, A., Khan, G. Y., et al. (2011). Clonal transmission, dual peak, and off-season cholera in Bangladesh. Infect. Ecol. Epidemiol. 1:7273. doi: 10.3402/iee.vli0.7273

Alam, M., Sadique, A., Bhuiyan, N. A., Nair, G. B., Siddique, A., Sack, D. A., et al. (2006). Effect of transport at ambient temperature on detection and isolation of Vibrio cholerae from environmental samples. Appl. Environ. Microbiol. 72, 2185-2190. doi: 10.1128/AEM.72.3.2185-2190.2006

Alam, M., Sultana, M., Nair, G. B., Siddique, A., Hasan, N. A., Sack, R. B., et al. (2007). Viable but nonculturable Vibrio cholerae O1 in biofilms in the aquatic environment and their role in cholera transmission. Proc. Natl. Acad. Sci. U.S.A. 104, 17801-17806. doi: 10.1073/pnas.0705599104

Ali, M., Nelson, A. R., Lopez, A. L., and Sack, D. A. (2015). Updated global burden of cholera in endemic countries. PLoS Negl. Trop. Dis. 9:e0003832. doi: 10.1371/journal.pntd.0003832

Arita, M., Takeda, T., Honda, T., and Miwatani, T. (1986). Purification and characterization of Vibrio cholerae non-O1 heat-stable enterotoxin. Infect. Immun. 52, 45-49.

Awasthi, S. P., Asakura, M., Chowdhury, N., Neogi, S. B., Hinenoya, A., Golbar, H. M., et al. (2013). Novel cholix toxin variants, ADP-ribosylating toxins in Vibrio cholerae non-O1/non-O139 strains, and their pathogenicity. Infect. Immun. 81, 531-541. doi: 10.1128/IAI.00982-12

Azarian, T., Ali, A., Johnson, J. A., Jubair, M., Cella, E., Ciccozzi, M., et al. (2016). Non-toxigenic environmental Vibrio cholerae O1 strain from Haiti provides evidence of pre-pandemic cholera in Hispaniola. Sci. Rep. 6:36115. doi: $10.1038 /$ srep 36115

Bagchi, K., Echeverria, P., Arthur, J., Sethabutr, O., Serichantalergs, O., and Hoge, C. (1993). Epidemic of diarrhea caused by Vibrio cholerae non-O1 that produced heat-stable toxin among Khmers in a camp in Thailand. J. Clin. Microbiol. 31, 1315-1317.

Belton, B., Karim, M., Thilsted, S., Collis, W., and Phillips, M. (2011). Review of Aquaculture and Fish Consumption in Bangladesh. Studies and Reviews 2011-53. Penang: The WorldFish Center.

Bhaumik, U. (2017). Fisheries of indian shad (Tenualosa ilisha) in the hooghlybhagirathi stretch of the ganga river system. Aquat. Ecosyst. Health Manag. 20, 130-139. doi: 10.1080/14634988.2017.1283894

Bhuyan, S. K., Vairale, M. G., Arya, N., Yadav, P., Veer, V., Singh, L., et al. (2016). Molecular epidemiology of Vibrio cholerae associated with flood in Brahamputra River valley, Assam, India. Infect. Genet. Evol. 40, 352-356. doi: 10.1016/j.meegid.2015.11.029

Blackstone, G. M., Nordstrom, J. L., Bowen, M. D., Meyer, R. F., Imbro, P., and DePaola, A. (2007). Use of a real time PCR assay for detection of the $\operatorname{ctxA}$ gene of Vibrio cholerae in an environmental survey of Mobile Bay. J. Microbiol. Methods 68, 254-259. doi: 10.1016/j.mimet.2006.08.006

Brayton, P., Tamplin, M., Huq, A., and Colwell, R. (1987). Enumeration of Vibrio cholerae $\mathrm{O} 1$ in Bangladesh waters by fluorescent-antibody direct viable count. Appl. Environ. Microbiol. 53, 2862-2865.

Chatterjee, D., and Chaudhuri, K. (2013). Vibrio cholerae O395 outer membrane vesicles modulate intestinal epithelial cells in a NOD1 protein-dependent

\section{ACKNOWLEDGMENTS}

We thank Rebeca Sultana for her contribution in developing the GIS map.

\section{SUPPLEMENTARY MATERIAL}

The Supplementary Material for this article can be found online at: https://www.frontiersin.org/articles/10.3389/fmicb. 2018.00222/full\#supplementary-material

manner and induce dendritic cell-mediated Th2/Th17 cell responses. J. Biol. Chem. 288, 4299-4309. doi: 10.1074/jbc.M112.408302

Chatterjee, S., Ghosh, K., Raychoudhuri, A., Chowdhury, G., Bhattacharya, M., Mukhopadhyay, A., et al. (2009). Incidence, virulence factors, and clonality among clinical strains of non-O1, non-O139 Vibrio cholerae isolates from hospitalized diarrheal patients in Kolkata, India. J. Clin. Microbiol. 47, 1087-1095. doi: 10.1128/JCM.02026-08

Choopun, N., Louis, V., Huq, A., and Colwell, R. R. (2002). Simple procedure for rapid identification of Vibrio cholerae from the aquatic environment. Appl. Environ. Microbiol. 68, 995-998. doi: 10.1128/aem.68.2.995-998.2002.

Coelho, A., Andrade, J. R., Vicente, A. C. P., and Dirita, V. J. (2000). Cytotoxic cell vacuolating activity from Vibrio cholerae hemolysin. Infect. Immun. 68, 1700-1705. doi: 10.1128/IAI.68.3.1700-1705.2000

Colwell, R. R. (1996). Global climate and infectious disease: the cholera paradigm. Science 274:2025. doi: 10.1126/science.274.5295.2025

Dalsgaard, A., Albert, M. J., Taylor, D., Shimada, T., Meza, R., Serichantalergs, O., et al. (1995). Characterization of Vibrio cholerae non-O1 serogroups obtained from an outbreak of diarrhea in Lima, Peru. J. Clin. Microbiol. 33, 2715-2722.

Dalsgaard, A., Forslund, A., Bodhidatta, L., Serichantalergs, O., Pitarangsi, C., Pang, L., et al. (1999). A high proportion of Vibrio cholerae strains isolated from children with diarrhoea in Bangkok, Thailand are multiple antibiotic resistant and belong to heterogenous non-O1, non-O139 O-serotypes. Epidemiol. Infect. 122, 217-226. doi: 10.1017/S0950268899002137

De, S. N., and Chatterje, D. (1953). An experimental study of the mechanism of action of Vibrio cholerae on the intestinal mucous membrane. J. Pathol. 66, 559-562. doi: 10.1002/path.1700660228

Debellis, L., Diana, A., Arcidiacono, D., Fiorotto, R., Portincasa, P., Altomare, D. F., et al. (2009). The Vibrio cholerae cytolysin promotes chloride secretion from intact human intestinal mucosa. PLoS ONE 4:e5074. doi: 10.1371/journal.pone.0005074

De Medici, D., Croci, L., Delibato, E., Di Pasquale, S., Filetici, E., and Toti, L. (2003). Evaluation of DNA extraction methods for use in combination with SYBR green I real-time PCR to detect Salmonella enterica serotype enteritidis in poultry. Appl. Environ. Microbiol. 69, 3456-3461. doi: 10.1128/AEM.69.6.3456-3461.2003

Didelot, X., and Falush, D. (2007). Inference of bacterial microevolution using multilocus sequence data. Genetics 175, 1251-1266. doi: 10.1534/genetics.106.063305

Du Preez, M., Van der Merwe, M., Cumbana, A., and Le Roux, W. (2010). A survey of Vibrio cholerae $\mathrm{O} 1$ and $\mathrm{O} 139$ in estuarine waters and sediments of Beira, Mozambique. Water SA 36, 615-620. doi: 10.4314/wsa.v36i5.61995

Dziejman, M., Serruto, D., Tam, V. C., Sturtevant, D., Diraphat, P., Faruque, S. M., et al. (2005). Genomic characterization of non-O1, non-O139 Vibrio cholerae reveals genes for a type III secretion system. Proc. Natl. Acad. Sci. U.S.A. 102, 3465-3470. doi: 10.1073/pnas.0409918102

Faruque, S. M., Albert, M. J., and Mekalanos, J. J. (1998). Epidemiology, genetics, and ecology of toxigenic Vibrio cholerae. Microbiol. Mol. Biol. Rev. 62, 1301-1314.

Faruque, S. M., Naser, I. B., Islam, M. J., Faruque, A., Ghosh, A., Nair, G. B., et al. (2005). Seasonal epidemics of cholera inversely correlate with the prevalence of environmental cholera phages. Proc. Natl. Acad. Sci. U.S.A. 102, 1702-1707. doi: 10.1073/pnas.0408992102 
Forssman, B., Mannes, T., Musto, J., Gottlieb, T., Robertson, G., Natoli, J. D., et al. (2007). Vibrio cholerae O1 El Tor cluster in Sydney linked to imported whitebait. Med. J. Aus. 187, 345-347.

Grant, S. L., Tamason, C. C., Hoque, B. A., and Jensen, P. K. M. (2015). Drinking cholera: salinity levels and palatability of drinking water in coastal Bangladesh. Trop. Med. Int. Health 20, 455-461. doi: 10.1111/tmi.12455

Guttman, D. S., and Dykhuizen, D. E. (1994). Clonal divergence in Escherichia coli as a result of recombination, not mutation. Science 266, 1380-1383. doi: $10.1126 /$ science.7973728

Halpern, M., and Izhaki, I. (2017). Fish as hosts of Vibrio cholerae. Front. Microbiol. 8:282. doi: $10.3389 /$ fmicb.2017.00282.

Halpern, M., Senderovich, Y., and Izhaki, I. (2008). Waterfowl-the missing link in epidemic and pandemic cholera dissemination? PLoS Pathog. 4:e1000173. doi: 10.1371/journal.ppat.1000173

Harris, J. (2012). F, Ryan, ET, and Calderwood, SB. Cholera. Lancet 379, 2466-2476. doi: 10.1016/S0140-6736(12)60436-X

Hasan, N. A., Choi, S. Y., Eppinger, M., Clark, P. W., Chen, A., Alam, M., et al. (2012). Genomic diversity of 2010 Haitian cholera outbreak strains. Proc. Natl. Acad. Sci. U.S.A. 109, E2010-E2017. doi: 10.1073/pnas.12073 59109

Hodges, K., and Gill, R. (2010). Infectious diarrhea: cellular and molecular mechanisms. Gut. Microb. 1, 4-21. doi: 10.4161/gmic.1.1.11036

Hounmanou, Y. M. G., Mdegela, R. H., Dougnon, T. V., Mhongole, O. J., Mayila, E. S., Malakalinga, J., et al. (2016). Toxigenic Vibrio cholerae O1 in vegetables and fish raised in wastewater irrigated fields and stabilization ponds during a non-cholera outbreak period in Morogoro, Tanzania: an environmental health study. BMC Res. Notes 9:466. doi: 10.1186/s13104-016-2283-0.

Huq, A., Colwell, R. R., Rahman, R., Ali, A., Chowdhury, M., Parveen, S., et al. (1990). Detection of Vibrio cholerae O1 in the aquatic environment by fluorescent-monoclonal antibody and culture methods. Appl. Environ. Microbiol. 56, 2370-2373.

Huq, A., Haley, B. J., Taviani, E., Chen, A., Hasan, N. A., and Colwell, R. R. (2012). Detection, isolation, and identification of Vibrio cholerae from the environment. Curr. Protoc. Microbiol. Chapter 6:Unit 6A.5. doi: 10.1002/9780471729259.mc06a05s26

Huq, A., Small, E. B., West, P. A., Huq, M. I., Rahman, R., and Colwell, R. R. (1983). Ecological relationships between Vibrio cholerae and planktonic crustacean copepods. Appl. Environ. Microbiol. 45, 275-283.

Igbinosa, E. O., and Okoh, A. I. (2008). Emerging Vibrio species: an unending threat to public health in developing countries. Res. Microbiol. 159, 495-506. doi: 10.1016/j.resmic.2008.07.001

Islam, A., Labbate, M., Djordjevic, S. P., Alam, M., Darling, A., Melvold, J., et al. (2013). Indigenous Vibrio cholerae strains from a non-endemic region are pathogenic. Open Biol. 3:120181. doi: 10.1098/rsob.120181

Islam, M. M., Mohammed, E. Y., and Ali, L. (2016). Economic incentives for sustainable hilsa fishing in Bangladesh: an analysis of the legal and institutional framework. Mar. Policy 68, 8-22. doi: 10.1016/j.marpol.2016.0 2.005

Jones, J., Benner Jr, R., DePaola, A., and Hara-Kudo, Y. (2013). Vibrio densities in the intestinal contents of finfish from coastal alabama. Agric. Food Anal. Bacteriol. 3, 186-194.

Jørgensen, R., Purdy, A. E., Fieldhouse, R. J., Kimber, M. S., Bartlett, D. H., and Merrill, A. R. (2008). Cholix toxin, a novel ADP-ribosylating factor from Vibrio cholerae. J. Biol. Chem. 283, 10671-10678. doi: 10.1074/jbc.M710 008200

Jutla, A. S., Akanda, A. S., and Islam, S. (2010). Tracking cholera in coastal regions using satellite observations. J. Am. Water Resour. Assoc. 46, 651-662. doi: 10.1111/j.1752-1688.2010.00448.x.

Kaper, J. B., Morris, J. G. Jr., and Levine, M. M. (1995). Cholera. Clin. Microbiol. Rev. 8, 48-86.

Kiiyukia, C., Nakajima, A., Nakai, T., Muroga, K., Kawakami, H., and Hashimoto, H. (1992). Vibrio cholerae non-O1 isolated from ayu fish (Plecoglossus altivelis) in Japan. Appl. Environ. Microbiol. 58, 3078-3082.

Koley., H., Mitra, R., Basu, A., Mukhopadhyay, A. K., Saha, P., Ramakrishna, B., et al. (1999). Response of wild-type mutants of Vibrio cholerae O1 possessing different combinations of virulence genes in the ligated rabbit ileal loop and in Ussing chambers: evidence for the presence of additional secretogen. J. Med. Microbiol. 48, 51-57. doi: 10.1099/00222615-48-1-51
Kumar, R., and Lalitha, K. V. (2013). Prevalence and molecular characterization of Vibrio cholerae O1, non-O1 and non-O139 in tropical seafood in Cochin, India. Foodborne Pathog. Dis. 10, 278-283. doi: 10.1089/fpd.2012 .1310

Lipp, E. K., Huq, A., and Colwell, R. R. (2002). Effects of global climate on infectious disease: the cholera model. Clin. Microbiol. Rev. 15, 757-770. doi: 10.1128/CMR.15.4.757-77 0.2002

Maggi, P., Carbonara, S., Fico, C., Santantonio, T., Romanelli, C., Sforza, E., et al. (1997). Epidemiological, clinical and therapeutic evaluation of the Italian cholera epidemic in 1994. Eur. J. Epidemiol. 13, 95-97. doi: 10.1023/A:1007329 700125

McIntyre, R. C., Tira, T., Flood, T., and Blake, P. (1979). Modes of transmission of cholera in a newly infected population on an atoll: implications for control measures. Lancet 313, 311-314. doi: 10.1016/S0140-6736(79)90 719-0

Mishra, A., Taneja, N., and Sharma, M. (2012). Environmental and epidemiological surveillance of Vibrio cholerae in a cholera-endemic region in India with freshwater environs. J. Appl. Microbiol. 112, 225-237. doi: 10.1111/j.1365-2672.2011.05191.x.

Morris Jr, J. G., and Black, R. E. (1985). Cholera and other vibrioses in the United States. N. Engl. J. Med. 312, 343-350. doi: 10.1056/NEJM198502073120604

Mrityunjoy, A., Kaniz. F., Fahmida, J., Shanzida, J. S., Md-Aftab, U., and Rashed, N. (2013). Prevalence of Vibrio cholerae in different food samples in the city of Dhaka, Bangladesh. Int. Food Res. J. 20, 1017-1022.

Nair, G., Oku, Y., Takeda, Y., Ghosh, A., Ghosh, R., Chattopadhyay, S., et al. (1988). Toxin profiles of Vibrio cholerae non-O1 from environmental sources in Calcutta, India. Appl. Environ. Microbiol. 54, 3180-3182.

Nandi, B., Nandy, R. K., Mukhopadhyay, S., Nair, G. B., Shimada, T., and Ghose, A. C. (2000). Rapid method for species-specific identification of Vibrio cholerae using primers targeted to the gene of outer membrane protein ompW. J. Clin. Microbiol. 38, 4145-4151.

Octavia, S., Salim, A., Kurniawan, J., Lam, C., Leung, Q., Ahsan, S., et al. (2013). Population structure and evolution of non-O1/non-O139 Vibrio cholerae by multilocus sequence typing. PLoS ONE 8:e65342. doi: 10.1371/journal.pone.0065342

Onifade, T., Hutchinson, R., Van Zile, K., Bodager, D., Baker, R., and Blackmore, C. (2011). Toxin producing Vibrio cholerae O75 outbreak, United States, March to April 2011. Euro Surveill. 16:19870. Available online at: http://www. eurosurveillance.org/ViewArticle.aspx?ArticleId=19870

Onyuka, J. H., Kakai, R., Onyango, D. M., Arama, P. F., and Gichuki, J. (2011). Prevalence and antimicrobial susceptibility patterns of enteric bacteria isolated from water and fish in lake victoria basin of western Kenya. World Acad. Sci. Eng. Technol. 5, 131-138.

Pandit, C., and Hora, S. (1951). The probable role of the hilsa fish, hilsa ilisha (ham) in maintaining cholera endemicity in India. Indian J. M. Sci. 5, 343-356.

Patel, J., Cockerill, I. I. I., F., Alder, J., Bradford, P., Eliopoulos, G., Hardy, D., et al. (2014). M100-S24: Performance Standards for Antimicrobial Susceptibility Testing; Twenty-Fourth Informational Supplement. Wayne, PA: The Clinical and Laboratory Standards Institute (CLSI).

Purdy, A. E., Balch, D., Lizárraga-Partida, M. L., Islam, M. S., Martinez-Urtaza, J., Huq, A., et al. (2010). Diversity and distribution of cholix toxin, a novel ADPribosylating factor from Vibrio cholerae. Environ. Microbiol. Rep. 2, 198-207. doi: 10.1111/j.1758-2229.2010.00139.x

Rajpara, N., Vinothkumar, K., Mohanty, P., Singh, A. K., Singh, R., Sinha, R., et al. (2013). Synergistic effect of various virulence factors leading to high toxicity of environmental $V$. cholerae NonO1/Non-O139 isolates lacking ctx gene: comparative study with clinical strains. PLoS ONE 8:e76200. doi: 10.1371/journal.pone.00 76200

Ramamurthy, T., Bag, P. K., Pal, A., Bhattacharya, S., Bhattacharya, M., Shimada, T., et al. (1993). Virulence patterns of Vibrio cholerae non-O1 strains isolated from hospitalised patients with acute diarrhoea in Calcutta, India. J. Med. Microbiol. 39, 310-317. doi: 10.1099/00222615-39-4-310

Rehulka, J., Petras, P., Marejkova, M., and Aldova, E. (2015). Vibrio cholerae nonO1/non-O139 infection in fish in the Czech Republic. Vet. Med. Czech. 60, 16-22. doi: 10.17221/7921-VETMED 
Ritchie, J. M., and Waldor, M. K. (2009). Vibrio cholerae interactions with the gastrointestinal tract: lessons from animal studies. Curr. Top. Microbiol. Immunol. 337, 37-59. doi: 10.1007/978-3-642-01846-6_2

Rivera, I. N. G., Chun, J., Huq, A., Sack, R. B., and Colwell, R. R. (2001). Genotypes associated with virulence in environmental isolates of Vibrio cholerae. Appl. Environ. Microbiol. 67, 2421-2429. doi: 10.1128/aem.67.6.2421-2429.2001

Rudra, S., Mahajan, R., Mathur, M., Kathuria, K., and Talwar, V. (1996). Cluster of cases of clinical cholera due to Vibrio cholerae 010 in east Delhi. Indian J. Med. Res. 103, 71-73.

Sanyal, S., Neogi, P., Alam, K., Huq, M., and Al-Mahmud, K. (1984). A new enterotoxin produced by Vibrio cholerae O1. J. Diarrhoeal Dis. Res. 2, 3-12

Sawasvirojwong, S., Srimanote, P., Chatsudthipong, V., and Muanprasat, C. (2013). An adult mouse model of Vibrio cholerae-induced diarrhea for studying pathogenesis and potential therapy of cholera. PLoS Negl. Trop. Dis. 7:e2293. doi: 10.1371/journal.pntd.0002293

Scheelbeek, P., Treglown, S., Reid, T., and Maes, P. (2009). Household fish preparation hygiene and cholera transmission in Monrovia, Liberia. J. Infect. Dev. Ctries. 3, 727-731. doi: 10.3855/jidc.615

Schürmann, D., Ebert, N., Kampf, D., Baumann, B., Frei, U., and Suttorp, N. (2002). Domestic cholera in Germany associated with fresh fish imported from Nigeria. Eur. J. Clin. Microbiol. Infect. Dis. 21, 827-828. doi: $10.1007 /$ s10096-002-0832-Z

Senderovich, Y., Izhaki, I., and Halpern, M. (2010). Fish as reservoirs and vectors of Vibrio cholerae. PLoS ONE 5:e8607. doi: 10.1371/journal.pone.0008607

Sharma, C., Thungapathra, M., Ghosh, A., Mukhopadhyay, A. K., Basu, A., Mitra, R., et al. (1998). Molecular analysis of Non-O1, Non-O139 Vibrio cholerae associated with an unusual upsurge in the incidence of cholera-like disease in Calcutta, India. J. Clin. Microbiol. 36, 756-763.

Shin, O. S., Tam, V. C., Suzuki, M., Ritchie, J. M., Bronson, R. T., Waldor, M. K., et al. (2011). Type III secretion is essential for the rapidly fatal diarrheal disease caused by non-O1, non-O139 Vibrio cholerae. MBio 2, e00106-e00111. doi: $10.1128 / \mathrm{mBio} .00106-11$

Singh, D., Matte, M. H., Matte, G., Jiang, S., Sabeena, F., Shukla, B., et al. (2001). Molecular analysis of Vibrio cholerae O1, O139, non-O1, and non-O139 strains: clonal relationships between clinical and environmental isolates. Appl. Environ. Microbiol. 67, 910-921. doi: 10.1128/AEM.67.2.910-92 1.2001

Tarr, C. L., Patel, J. S., Puhr, N. D., Sowers, E. G., Bopp, C. A., and Strockbine, N. A. (2007). Identification of Vibrio isolates by a multiplex
PCR assay and rpoB sequence determination. J. Clin. Microbiol. 45, 134-140. doi: 10.1128/JCM.01544-06

Thelin, K. H., and Taylor, R. K. (1996). Toxin-coregulated pilus, but not mannosesensitive hemagglutinin, is required for colonization by Vibrio cholerae $\mathrm{O} 1 \mathrm{El}$ Tor biotype and O139 strains. Infect. Immun. 64, 2853-2856.

Toma, C., Nakasone, N., Song, T., and Iwanaga, M. (2005). Vibrio cholerae SXT Element, Laos. Emerging Infect. Dis. 11, 346-347. doi: 10.3201/eid1102.040794

Traor,é, O., Martikainen, O., Siitonen, A., Traor,é, A. S., Barro, N., and Haukka, K. (2014). Occurrence of Vibrio cholerae in fish and water from a reservoir and a neighboring channel in Ouagadougou, Burkina Faso. J. Infect. Dev. Ctries. 8, 1334-1338. doi: 10.3855/jidc.3946

Unterweger, D., Kitaoka, M., Miyata, S. T., Bachmann, V., Brooks, T. M., Moloney, J., et al. (2012). Constitutive type VI secretion system expression gives Vibrio cholerae intra-and interspecific competitive advantages. PLoS ONE 7:e48320. doi: 10.1371/journal.pone.0048320

Wahed, T., Kaukab, S. S. T., Saha, N. C., Khan, I. A., Khanam, F., Chowdhury, F., et al. (2013). Knowledge of, attitudes toward, and preventive practices relating to cholera and oral cholera vaccine among urban high-risk groups: findings of a cross-sectional study in Dhaka, Bangladesh. BMC Public Health 13:242. doi: 10.1186/1471-2458-13-242

Waldor, M. K., Tschäpe, H., and Mekalanos, J. J. (1996). A new type of conjugative transposon encodes resistance to sulfamethoxazole, trimethoprim, and streptomycin in Vibrio cholerae O139. J. Bacteriol. 178, 4157-4165. doi: 10.1128/jb.178.14.4157-4165.1996

Wallis, T., Starkey, W., Stephen, J., Haddon, S., Osborne, M., and Candy, D. (1986). Enterotoxin production by Salmonella typhimurium strains of different virulence. J. Med. Microbiol. 21, 19-23. doi: 10.1099/00222615-21-1-19

Conflict of Interest Statement: The authors declare that the research was conducted in the absence of any commercial or financial relationships that could be construed as a potential conflict of interest.

Copyright (C) 2018 Hossain, Farhana, Tulsiani, Begum and Jensen. This is an openaccess article distributed under the terms of the Creative Commons Attribution License (CC BY). The use, distribution or reproduction in other forums is permitted, provided the original author(s) and the copyright owner are credited and that the original publication in this journal is cited, in accordance with accepted academic practice. No use, distribution or reproduction is permitted which does not comply with these terms. 